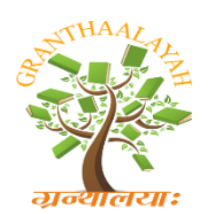

INTERNATIONAL JOURNAL OF RESEARCH GRANTHAALAYAH A knowledge Repository

Management

\title{
PERCEPTION ON PRADHAN MANTRI JANDHAN YOJANA - A STUDY WITH REFERENCE TO THALLAREVU MANDAL
}

\author{
Mohana Krishna Irrinki ${ }^{* 1}$, Kuberudu Burlakanti ${ }^{2}$ \\ ${ }^{* 1}$ Research Scholar, JNTUK, Kakinada, Andhra Pradesh, India \\ ${ }^{2}$ Professor \& HoD, Department of MBA, AUMSN PG Center, Kakinada, Andhra Pradesh, India \\ DOI: https://doi.org/10.29121/granthaalayah.v5.i6.2017.2006
}

\begin{abstract}
Financial inclusion aims at delivering the financial services at an affordable cost to sections of disadvantaged and low-income segments of society. Financial inclusion is an innovative concept which promotes the banking habits among the financially excluded people and enables to reduce poverty and the launch of Pradhan Mantri Jan Dhan Yojana (PMJDY) by Government of India is in that direction. This scheme is not confined to opening of bank account but has other advantages blended with it such as Zero Balance bank account with RuPay debit card, Accidental Insurance cover of Rs 1 lakh, Life Insurance cover of Rs 30,000, etc. This paper is an attempt to identify the perception of the people of Thallarevu Mandal about the newly launched scheme Pradhan Mantri Jan Dhan Yojana.
\end{abstract}

Keywords: Financial Inclusion; Pradhan Mantri Jan Dhan Yojana; Debit Cards; Insurance; Financial Services; Banking Services.

Cite This Article: Mohana Krishna Irrinki, and Kuberudu Burlakanti. (2017). "PERCEPTION ON PRADHAN MANTRI JANDHAN YOJANA - A STUDY WITH REFERENCE TO THALLAREVU MANDAL." International Journal of Research - Granthaalayah, 5(6), 129-146. https://doi.org/10.29121/granthaalayah.v5.i6.2017.2006.

\section{Introduction}

Even after 48 years of nationalisation of banks in 1969, a large section of the population and mostly the rural areas still remain unbanked. Due to this most of the poor and lower income groups are unable to access the financial products and services. The main objective of financial inclusion is to promote sustainable development, generate employment and alleviate poverty in rural areas by supplying various financial services to the financially excluded people.

Government of India (2008) defines Financial inclusion as the process of ensuring access to financial services and timely and adequate credit where needed by vulnerable groups such as weaker sections and low income groups at an affordable cost. 
According to the Planning Commission (2009), Financial Inclusion refers to universal access to a wide range of financial services at a reasonable cost. These include not only banking products but also other financial services such as insurance and equity products.

Strong financial institutions are the pillars of the economic growth and progress. Lack of access and appropriate financial services is a global problem. The significance of an inclusive financial system has become a policy priority in many countries. Access to the financial services and products will boost the financial condition and improve the standard of living of the financially excluded citizens of the country.

Indian banking sector has realized the importance of financial inclusion and in accordance to this several initiatives is started over the last two and half decades. As a part of banking reforms new foreign and private banks were started in the countries which lead to induction of new technologies and competition into the banking sector. This all lead to the improvement of the banking facilities which finally benefitted the customers.

Financial inclusion plays a big role in eradicating the poverty in the country. The process for achieving sustainable development and inclusive growth is primarily known as financial inclusion. To provide financial literacy and financial inclusion, the financial stability and development council under the ministry of finance, Government of India is committed and all the financial institutes like RBI, Scheduled commercial banks, financial sector regulators are directed to achieve this objective.

The countries where large portion of population is excluded from formal financial institutes have higher rate of poverty and income inequality. Linking the poor to service of formal financial institute help the poor to tackle poverty as well as it increases the rate of growth and development of the country. The banking sector plays a key role in achieving the inclusive growth and financial inclusion. Financial inclusion secures the family with insurance, providing credit and over draft to the needed. These measures will provide a path where there is an eradication of poverty.

However there are many barriers and difficulties in achieving complete financial inclusion. There are many challenges like coverage of remote area which are completely out of reach of banks and involve higher costs to banks. Using small infrastructures to open new branches in the uncovered remote areas, development of new products as per the requirement of the poor people and developing a system where the financial institutions, NGOs, financial regulatory agencies etc. collaborate and coordinate to bring the financial inclusion.

In general, where people have linkages with the financial institutions through holding bank account, insurance policy etc. is called financial inclusion. It helps the people to have affordable access to financial services. It increases the GDP growth and circulation of currency. The country has taken several steps towards financial inclusion. The main objective of these steps is to provide banking services at an affordable cost to the weaker section of the society. To attain financial literacy the government and financial regulatory bodies are encouraging the financial institutions. 


\section{Pradhan Mantri Jan Dhan Yogana}

The main objective of PMJDY is to provide access to the people to various financial services such as overdraft facility, credit facility, both life and accidental insurance, pension etc. It is taken up as a challenge to provide financial inclusion to all the citizens of the country. The scheme aims at the goal of having at least one bank account to the citizens of the country.

The scheme is run by Ministry of finance. On the very first day there have been more than 1.5 crore accounts being opened under this scheme. As of 31.01.2017 more than 27.64 crore bank accounts were opened and an amount of Rs 60257 crores was deposited in these accounts. Some of the key elements of PMJDY

- Banking facility for everyone.

- Financial inclusion

- Rupay debit card with overdraft facility

- Mobile banking for the poor

- Credit guarantee fund

- Micro insurance

\section{Action Plan for Implementing PMJDY}

There are two phases of this scheme in which the objective of financial inclusion of the poor People are to be achieved.

\section{Phase-I of PMJDY}

The first phase of this scheme starts from August 15, 2014 to August 14, 2015 which envisages the following:

- All households across the country have access to banking facilities with at least one Basic Bank Accounts with a bank branch or a fixed point Business Correspondent (BC).

- All households have RuPay Debit Card with Rs. 1 lakh inbuilt accident insurance covers.

- If bank account is operated satisfactorily for 6 months, Rs.5000 overdraft facility will be granted to only Aadhaar enabled accounts.

- Direct Benefit Transfer facility of various government schemes will be provided through bank accounts to the beneficiaries.

- The existing Kisan Credit Card is proposed to be issued as RuPay Kisan Card to the farmers.

- Financial literacy programme under the scheme will be implemented up to village level.

\section{Phase-II of PMJDY}

The period of Phase II is August 15, 2015 to August 14, 2018 which focuses on the following:

- Micro insurance will be provided to the people.

- Swavlamban - an unorganised sector pension scheme is to be proposed through the Business Correspondents.

- Households in hilly, tribal and difficult areas will be covered in this phase.

- This phase would also cover the remaining adults and students in households. 


\section{Scheme Details}

Pradhan Mantri Jan-Dhan Yojana (PMJDY) is National Mission for Financial Inclusion to ensure access to financial services, namely, Banking/ Savings \& Deposit Accounts, Remittance, Credit, Insurance, Pension in an affordable manner. Account can be opened in any bank branch or Business Correspondent (Bank Mitra) outlet. PMJDY accounts are being opened with Zero balance. However, if the account-holder wishes to get cheque book, he/she will have to fulfil minimum balance criteria.

Documents required opening an account under Pradhan Mantri Jan-Dhan Yojana

- If Aadhaar Card/Aadhaar Number is available then no other documents is required. If address has changed, then a self-certification of current address is sufficient.

- If Aadhaar Card is not available, then any one of the following Officially Valid Documents (OVD) is required: Voter ID Card, Driving License, PAN Card, and Passport $\&$ NREGA Card. If these documents also contain your address, it can serve both as Proof of Identity and Address.

- If a person does not have any of the "officially valid documents" mentioned above, but it is categorized as 'low risk' by the banks, then he/she can open a bank account by submitting any one of the following documents:

- Identity Card with applicant's photograph issued by Central/State Government Departments, Statutory/Regulatory Authorities, Public Sector Undertakings, Scheduled Commercial Banks and Public Financial Institutions;

- Letter issued by a gazette officer, with a duly attested photograph of the person.

\section{Objectives of the Study}

- To study the awareness levels of people about the PMJDY scheme

- To study the perceptions of the people about PMJDY scheme.

Present study is based on primary data which is collected through a questionnaire to study the awareness levels and perceptions of the people about PMJDY. The questionnaire consists of 16 questions and 20 statements related to Likert scale.

For the collection of data, 125 respondents from Thallarevu Mandal were taken using the nonrandom sampling. The sample consists of labourers, farmers, employed people, unemployed people, service people and students.

The data collected is analyses using the Percentage method and Factor analysis.

Factor analysis is a statistical method used to describe variability among observed, correlated variables in terms of a potentially lower number of unobserved variables called factors. Factor analysis aims to find independent latent variables. Each factor captures a certain amount of the overall variance in the observed variables and the factors are always listed in order of how much variation they explain. 


\section{Limitations of the Study}

The study is conducted in Thallarevu Mandal and the obtained results may not be applicable in other areas. The Mandal is vast in area and it is not possible to cover each and every unit in the sample in the available time. The sample size is very small and may not be a true picture of the whole universe.

\section{Review of Literature}

Kuldeep Singh and Anand Singh Koden (2011) ${ }^{\mathbf{1}}$ had utilized the financial inclusion index and analyzed the relationship between financial inclusion and development of the economy. In the study regression analysis is used and identified the factors associated with the financial inclusion. The study covered 15 states and were analyzed thoroughly and identified that there is positive correlation of financial inclusion and socio-economic development. Similarly it is observed that there is no significant relationship of gender, education and employment to financial inclusion.

Prabhu P V (2011) $)^{2}$ had explained that the progress in the financial sector has not reflected in the same manner among the poor. People who are deprived of access to the basic banking services are also the ones who are deprived of the benefits of economic growth. In order to overcome this there should be an inclusive growth for the betterment of the society. The paper studies the progress of Financial Inclusion through Credit co-operatives. To eradicate poverty there should be focus on the development of agricultural sector and rural economy in addition to the growth of other sectors of the economy. This will help to improve the GDP growth. The rural economy can be improved with the help of Co-operatives which is instrumental in dispensing the agricultural and rural credit to the rural population. Financial inclusion can be achieved through the effective involvement of co-operative and banking sectors in the disbursement of the credit among the rural people.

Leeladhar V, (2005) Banks would have to evolve specific strategies to expand the outreach of their services in order to promote financial inclusion. One of the ways in which this can be achieved in a cost-effective manner is through forging linkages with micro finance institutions and local communities. Banks should give wide publicity of no frills account. Banks need to redesign their business strategies to incorporate specific plans to promote financial inclusion of low income group treating it both a business opportunity as well as a corporate social responsibility.

\section{Data Analysis and Interpretation}

The data collected from the respondents through the questionnaire is analysed by percentage method and factor analysis. The data is presented in the form of tables and pictures.

Table 1: Gender wise distribution of the respondents

\begin{tabular}{|l|l|l|}
\hline \multicolumn{1}{|c|}{ Gender } & \multicolumn{1}{c|}{ No of Respondents } & \multicolumn{1}{c|}{ \% of Respondents } \\
\hline Female & 56 & 44.8 \\
\hline Male & 69 & 55.2 \\
\hline Grand Total & $\mathbf{1 2 5}$ & $\mathbf{1 0 0}$ \\
\hline
\end{tabular}




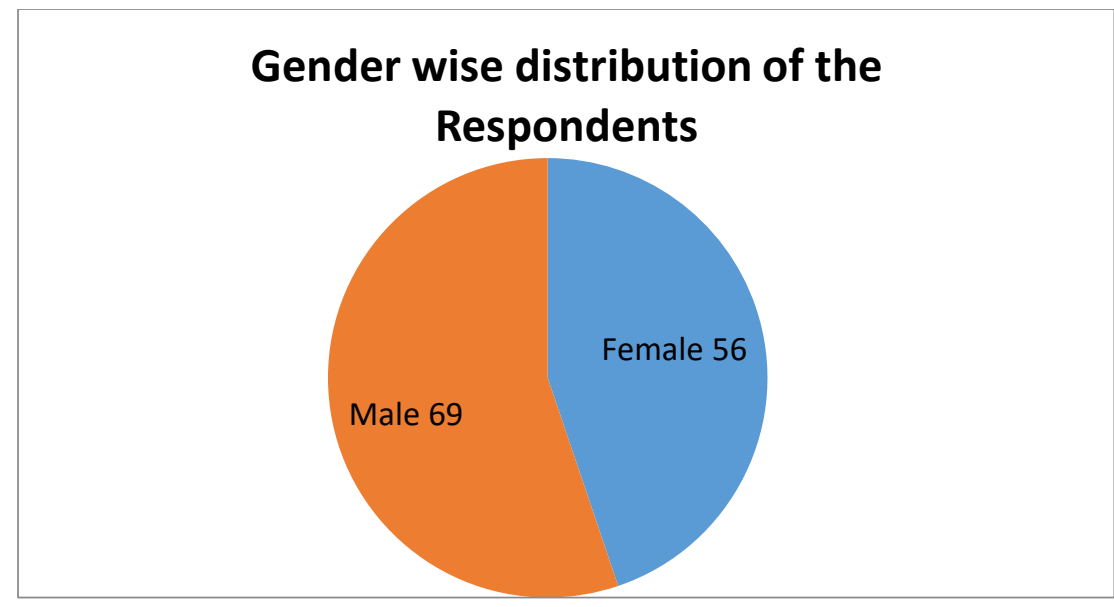

From the table 1 it is evident that out of the total 125 respondents, 56 (44.8\%) of the respondents are female and the remaining $69(55.2 \%)$ are male.

Table 2: Age wise distribution of the respondents

\begin{tabular}{|l|l|l|}
\hline \multicolumn{1}{|c|}{ Age } & \multicolumn{1}{c|}{ No of Respondent } & \% of Respondents \\
\hline $18-30$ & 63 & 50.4 \\
\hline $31-45$ & 45 & 36 \\
\hline $46-60$ & 10 & 8 \\
\hline More than 60 years & 7 & 5.6 \\
\hline Grand Total & 125 & 100 \\
\hline
\end{tabular}

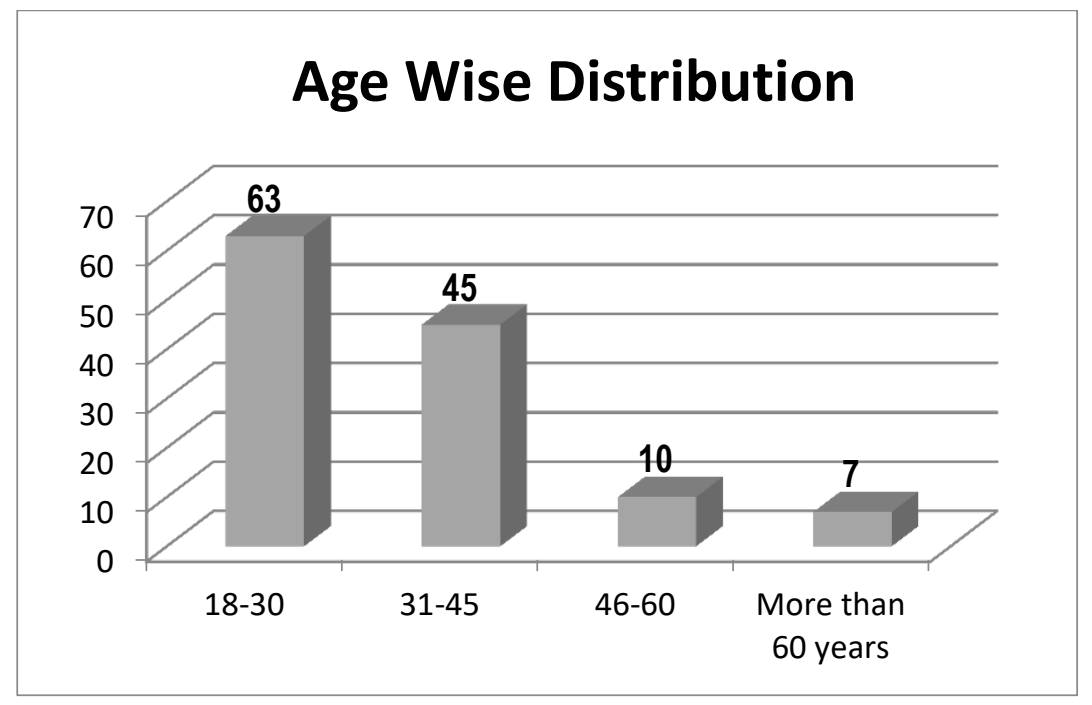

From Table 2 it is evident that most of the respondents 63 (50.4\%) are in the age group of 18-30 followed by $45(36 \%)$ in the 31-45 age group and 10 respondents are in the age group of 46-60 and 7 respondents are of more than 60 years of age. 
Table 3: Marital status of the respondents

\begin{tabular}{|l|l|l|}
\hline \multicolumn{1}{|c|}{ Marital Status } & \multicolumn{1}{c|}{ No of Respondents } & \multicolumn{1}{c|}{ \% of Respondents } \\
\hline Married & 72 & 57.6 \\
\hline Unmarried & 53 & 42.4 \\
\hline Grand Total & 125 & 100 \\
\hline
\end{tabular}

\section{Marital Status of Respondents}

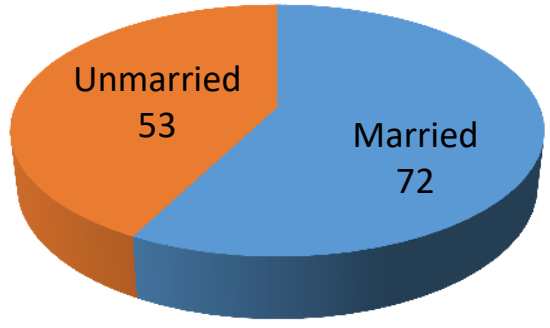

From the table 3 , it is evident that $72(57.6 \%)$ respondents out of 125 are married and the remaining $53(42.4 \%)$ are unmarried. Married respondents are more than those of unmarried.

Table 4: Educational Qualifications of the respondents

\begin{tabular}{|l|l|l|}
\hline Educational Qualification of the Respondent & No of Respondents & \% of Respondents \\
\hline Below SSC & 37 & 29.6 \\
\hline Graduation & 38 & 30.4 \\
\hline No Formal Education & 12 & 9.6 \\
\hline Post Graduation & 11 & 8.8 \\
\hline SSC / ITI / Diploma & 27 & 21.6 \\
\hline Grand Total & 125 & 100 \\
\hline
\end{tabular}

\section{Qualifications of Respondents}
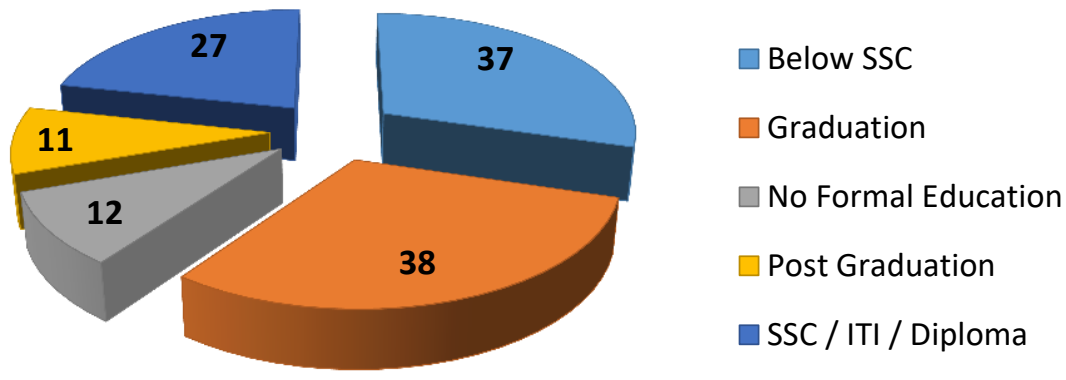
Table 4 shows that 38 (30.4\%) of the respondents are Graduated followed by 37 (29.6\%) have below SSC qualification. $27(21.6 \%)$ have completed their SSC/Diploma course. Post graduation is completed by 11 respondents and 12 have no formal education.

Table 5: Occupation of the respondents

\begin{tabular}{|l|l|l|}
\hline \multicolumn{1}{|c|}{ Occupation of the Respondent } & No of Respondents & \% of Respondents \\
\hline Agriculture Labour & 30 & 24 \\
\hline Farmer & 39 & 31.2 \\
\hline Professional & 13 & 10.4 \\
\hline Self Employed & 14 & 11.2 \\
\hline Student & 29 & 23.2 \\
\hline Grand Total & 125 & 100 \\
\hline
\end{tabular}

\section{Occupation of the Respondents}

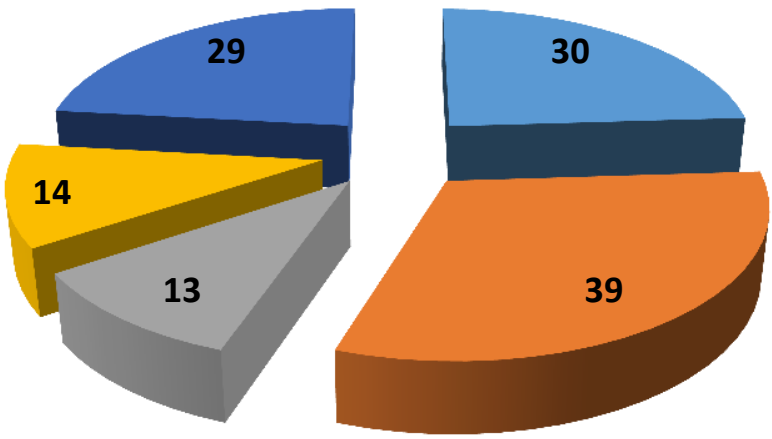

Agriculture Labour

Farmer

Professional

Self Employed

Student

Table 5 shows the occupation of the respondents. Most of the respondents belong to the agriculture sector. $39(31.2 \%)$ are farmers and 30 (24\%) are agricultural labour. Followed by students with $23.2 \%$ and $14(11.2 \%)$ respondents are self employed followed by $13(10.4 \%)$ professionals

Table 6: Income range of the respondents

\begin{tabular}{|l|l|l|}
\hline \multicolumn{1}{|c|}{ Income Range } & \multicolumn{1}{c|}{ No of Respondents } & \multicolumn{1}{c|}{ \% of Respondents } \\
\hline Upto 100000 & 92 & 73.6 \\
\hline Between 100001 to 200000 & 33 & 26.4 \\
\hline Grand Total & 125 & 100 \\
\hline
\end{tabular}




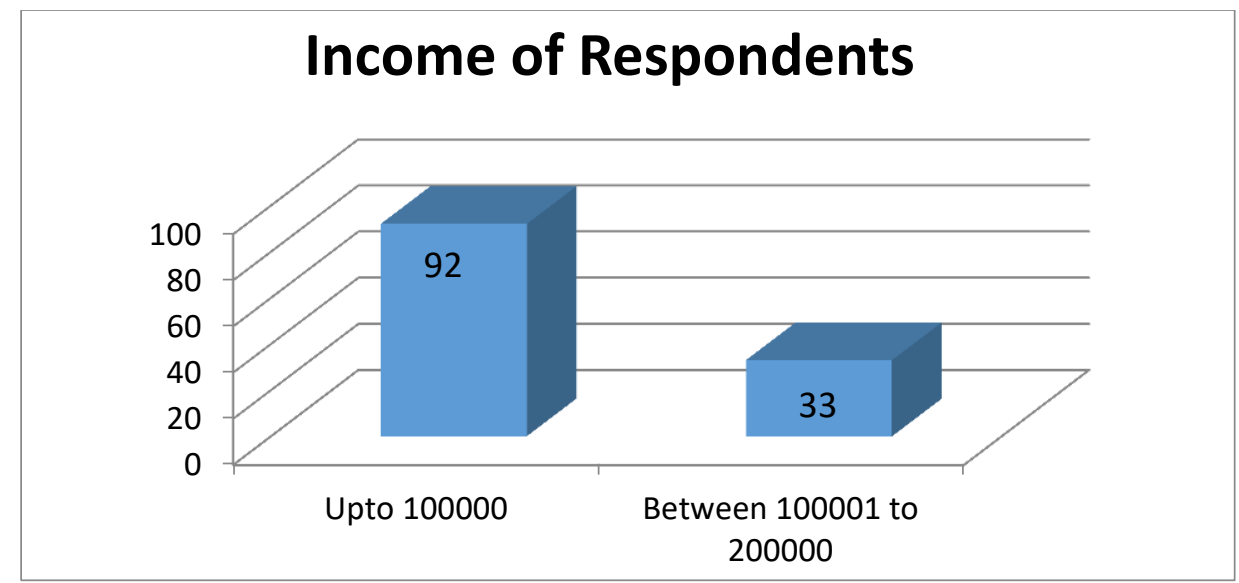

Table 6 shows that most of the respondents are having income below 100000. 92 (73.6\%) of the respondents are in this range followed by 33 (26.4\%) are having their income between 100001 and 200000.

Table 7: Awareness of the PMJDY among the respondents

\begin{tabular}{|l|l|l|}
\hline \multicolumn{1}{|c|}{ Aware of PMJDY } & \multicolumn{1}{c|}{ No of Respondents } & \multicolumn{1}{c|}{$\%$ of Respondents } \\
\hline No & 3 & 2.4 \\
\hline Yes & 122 & 97.6 \\
\hline Grand Total & 125 & 100 \\
\hline
\end{tabular}

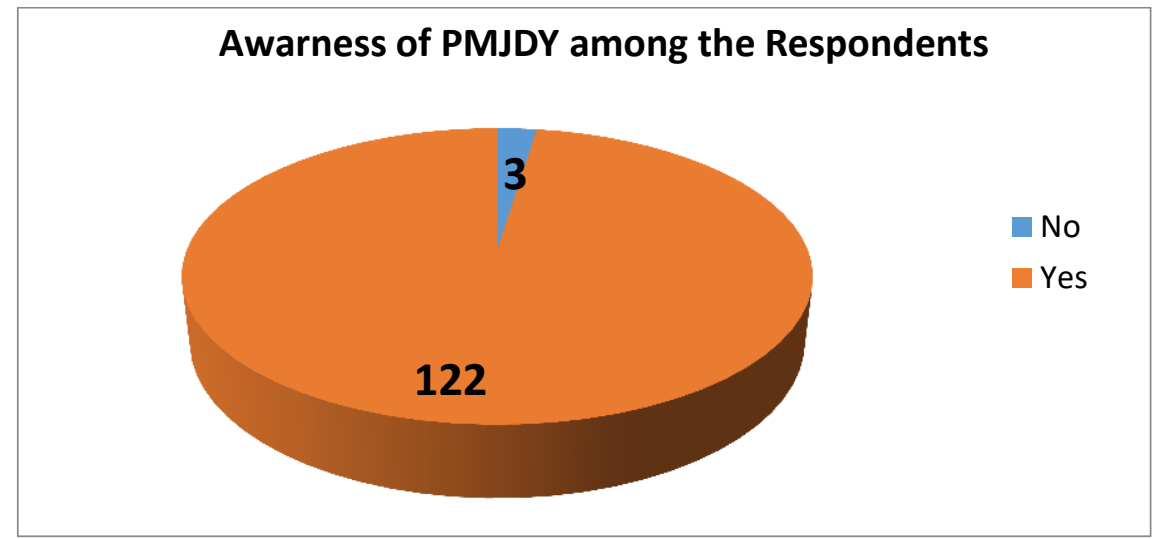

Table 7 shows that only $3(2.4 \%)$ respondents are not aware of PMJDY scheme. 122 (97.6\%) respondents are aware of the scheme.

Table 8: Awareness of the PMJDY among the respondents

\begin{tabular}{|l|l|l|}
\hline \multicolumn{1}{|c|}{ Aware of PMYDY through } & No of Respondents & \% of Respondents \\
\hline Bank Officials & 50 & 40 \\
\hline Friends \& Relatives & 26 & 20.8 \\
\hline
\end{tabular}




\begin{tabular}{|l|l|l|} 
Newspapers / Advertisements & 22 & 17.6 \\
\hline Not Aware & 3 & 2.4 \\
\hline Village Panchayat & 24 & 19.2 \\
\hline Grand Total & 125 & 100 \\
\hline
\end{tabular}

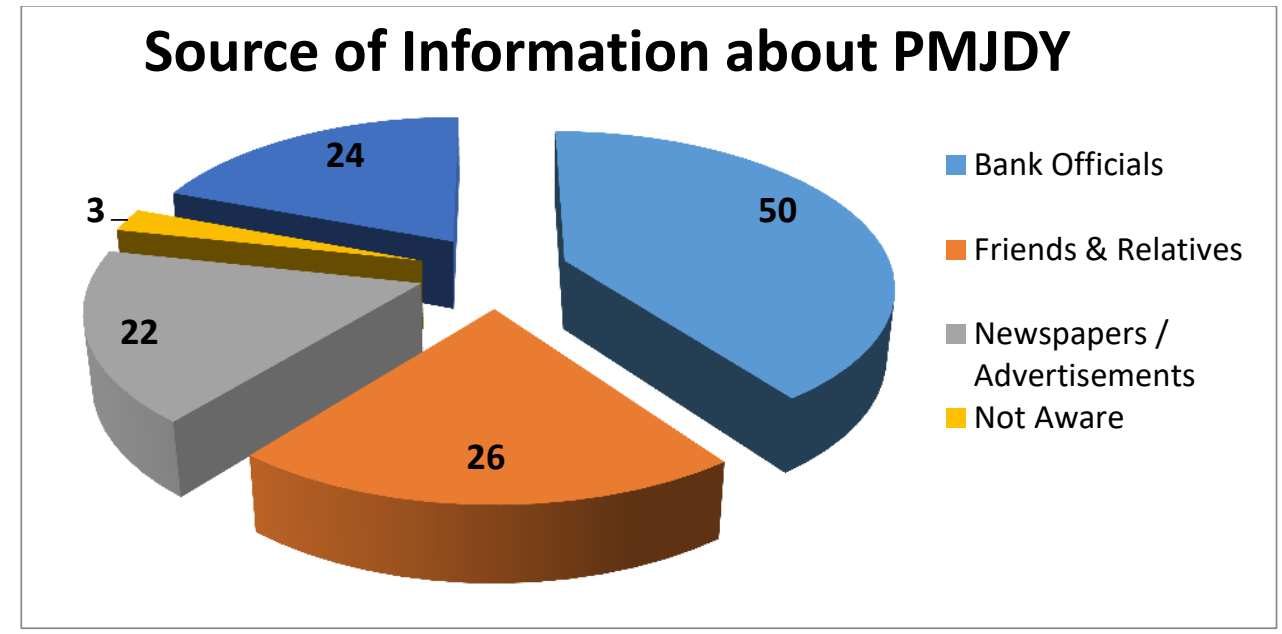

Table 8 provides information through whom the newly launched scheme is known through. 50 $(40 \%)$ of the respondents are aware of the scheme through bank officials followed by $26(20.8 \%)$ through Friends \& Relatives which is closely followed by 22 (17.6\%) through Newspapers / Advertisements. $24(19.2 \%)$ are aware of the scheme through Village Panchayat and 3 respondents are not aware of this scheme.

Table 9: Possession of an account under PMJDY

\begin{tabular}{|l|l|l|}
\hline \multicolumn{1}{|c|}{ Have a PMJDY Account } & \multicolumn{1}{c|}{ No of Respondents } & \% of Respondents \\
\hline No & 43 & 34.4 \\
\hline Yes & 82 & 65.6 \\
\hline Grand Total & 125 & 100 \\
\hline
\end{tabular}

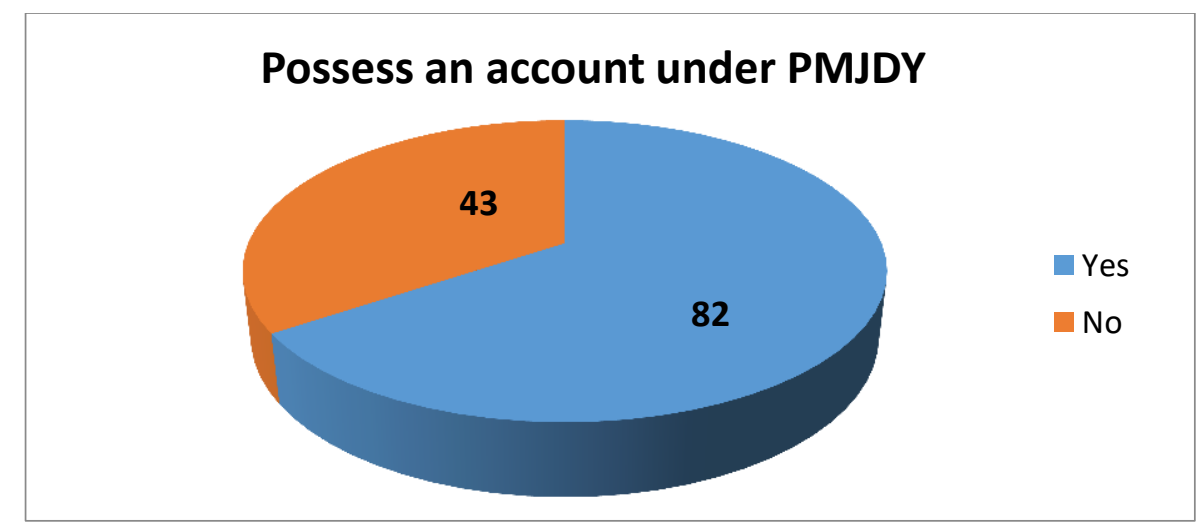


Table 9 shows that $82(65.6 \%)$ of the respondents are having an account under PMJDY. 43 (34.4\%) of the respondents are not having an account under the PMJDY scheme. One more important point that needs to be noted here is that the respondents are having a normal bank savings account and some of them are not having an account under the PMJDY scheme.

Table 10: Reason for opening an account under PMJDY

\begin{tabular}{|l|l|l|}
\hline \multicolumn{1}{|c|}{ Reason for opening of an account } & No of Respondents & \% of Respondents \\
\hline Savings Facility & 72 & 57.6 \\
\hline Insurance Facility & 4 & 3.2 \\
\hline Overdraft Facility & 6 & 4.8 \\
\hline No account under PMJDY & 43 & 34.4 \\
\hline Grand Total & 125 & 100 \\
\hline
\end{tabular}

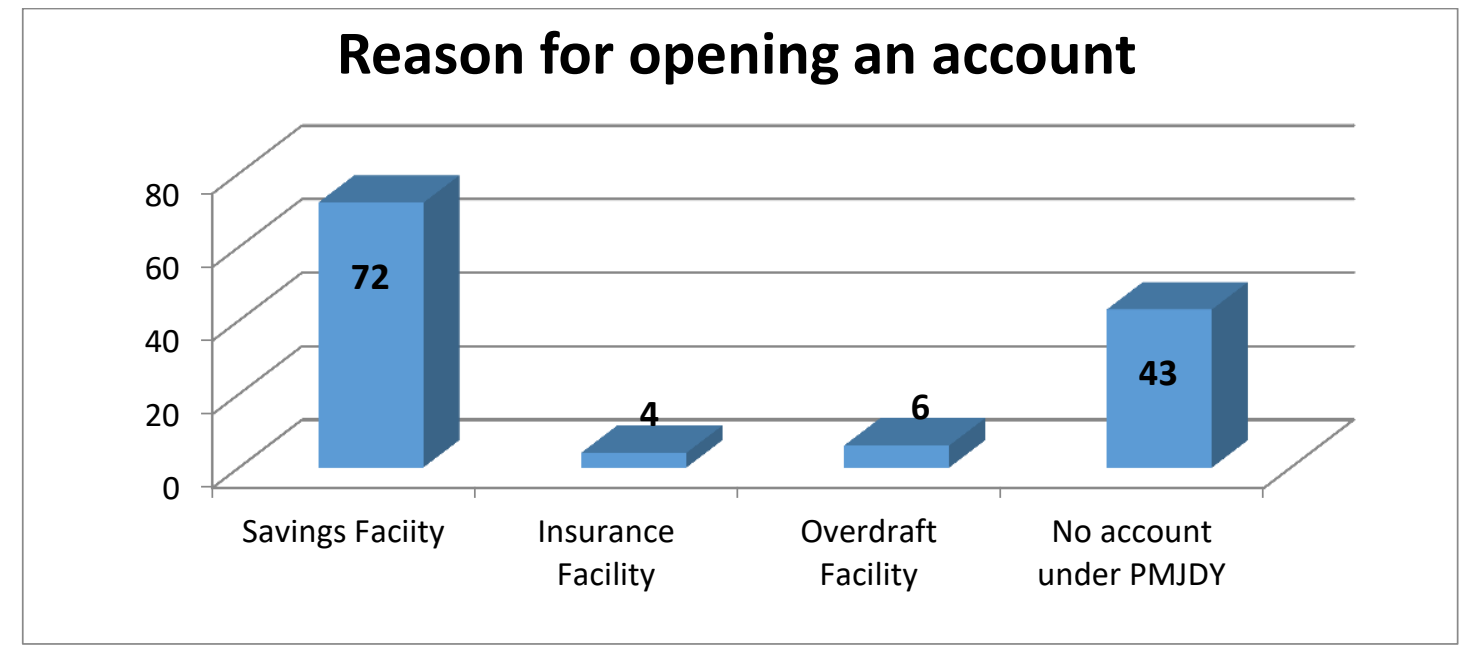

Table 10 shows the reasons for opening an account under PMJDY scheme. 72 (57.6\%) of the respondents have opened the account for saving purpose. $6(4.8 \%)$ of the respondents have opened the account for availing the overdraft facility followed by 4 (3.2\%) for utilising the insurance facility. There are $43(34.4 \%)$ of the respondents are not having an account under this scheme.

Table 11: Proof used for opening an account under PMJDY

\begin{tabular}{|l|l|l|}
\hline \multicolumn{1}{|c|}{ Proof used for opening an account } & No of Respondents & \% of Respondents \\
\hline Aadhar Card & 43 & 34.4 \\
\hline Ration Card & 31 & 24.8 \\
\hline Driving Licence & 3 & 2.4 \\
\hline Voter Card & 5 & 4 \\
\hline No account under PMJDY & 43 & 34.4 \\
\hline Grand Total & 125 & 100 \\
\hline
\end{tabular}




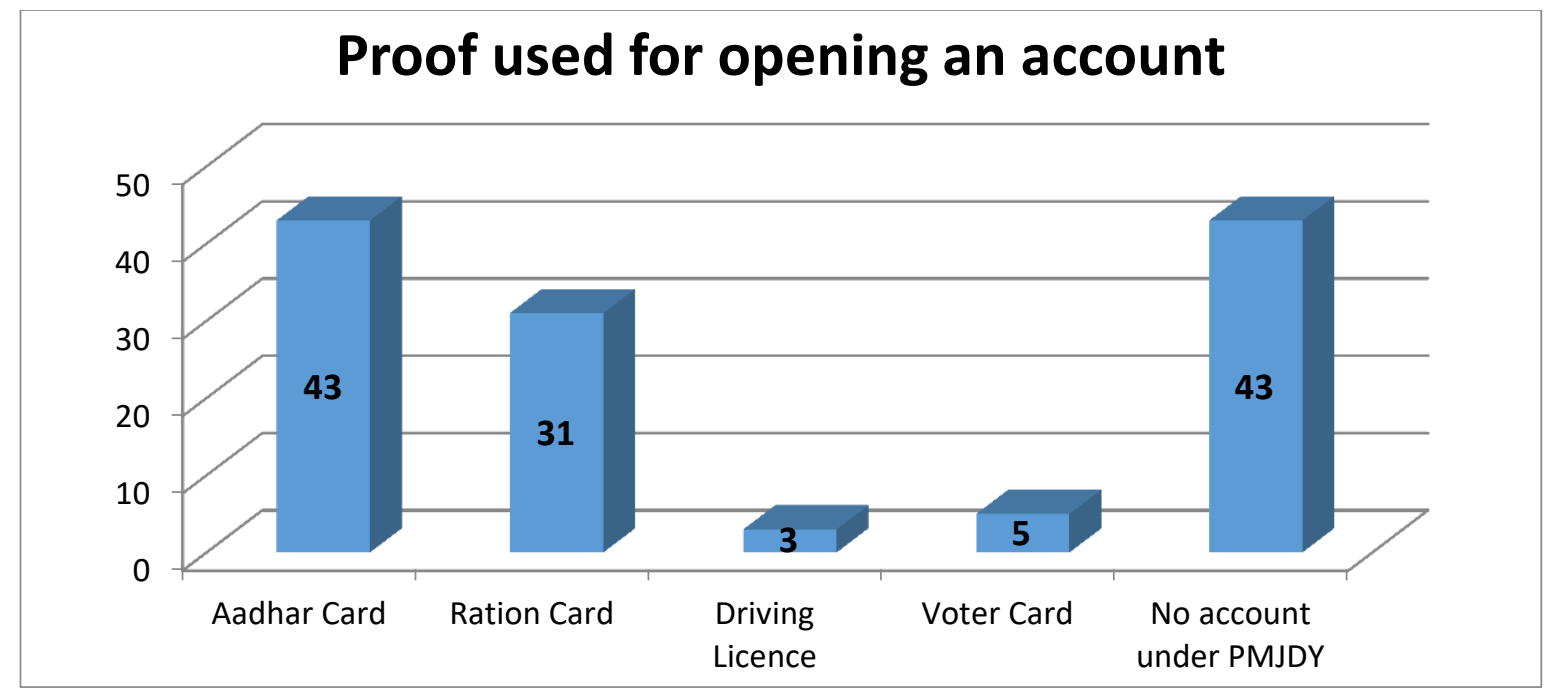

Table 11 shows that proof that are produced at the bank for opening an account under the PMJDY scheme. 43 (34.4\%) of the respondents have produced Aadhar card for opening the account followed by $31(24.8 \%)$ have produced Ration card for opening the account. Voter card is used by $5(4 \%)$ followed by $3(2.4 \%)$ of the respondents had given Driving Licence as proof for opening the account under the PMJDY scheme.

Table 12: Are timely benefits provided to the customers by the banks

\begin{tabular}{|l|l|l|}
\hline \multicolumn{1}{|c|}{ Benefits Provided } & No of Respondents & \% of Respondents \\
\hline Yes & 51 & 40.8 \\
\hline No & 31 & 24.8 \\
\hline No account under PMJDY & 43 & 34.4 \\
\hline Grand Total & 125 & 100 \\
\hline
\end{tabular}

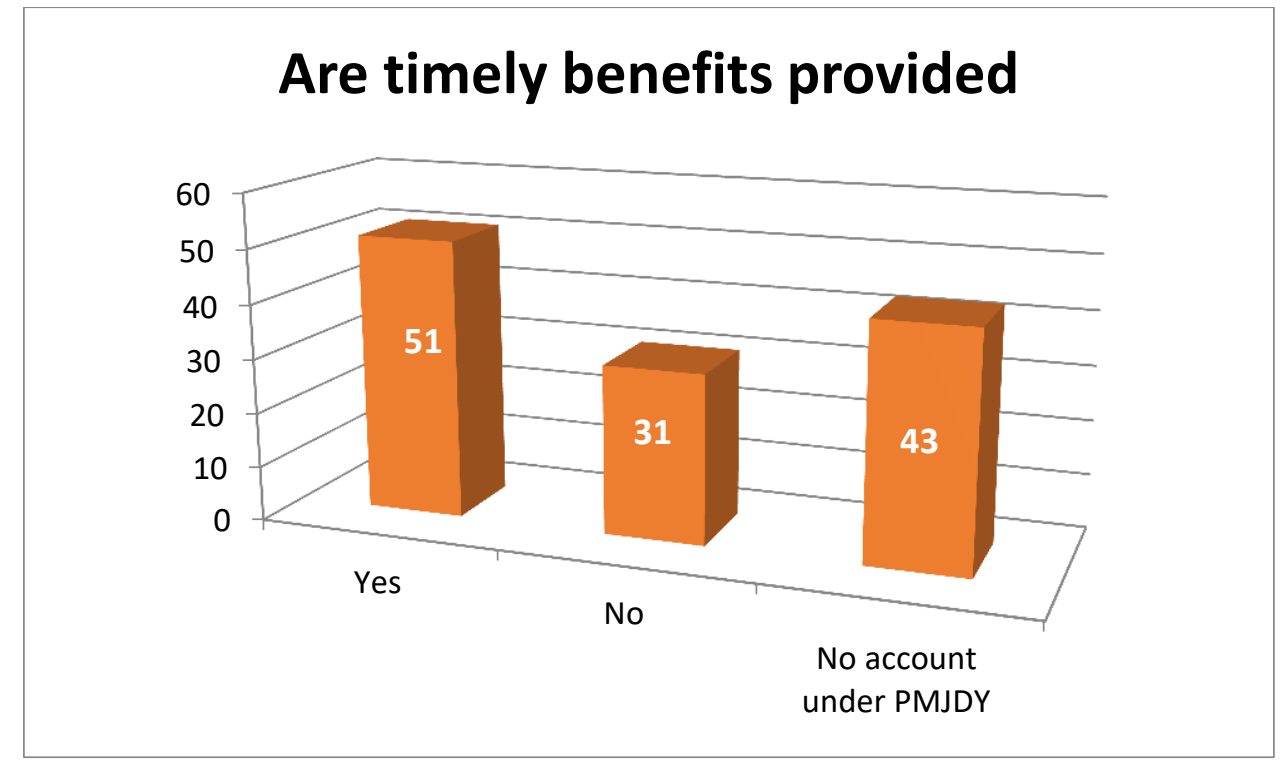


Table 12 shows that $51(40.8 \%)$ of the respondents feel that timely benefits are provided by the banks to the customers. $31(24.8 \%)$ of the respondents feel that timely benefits are not provided to the customers.

\section{Perception of People towards PMJDY}

20 statements were tabulated to analyse the perception towards PMJDY. Factor analysis is used to reduce large number of variables into a few set of variables. It is used to analyse the relationship between variables. To determine the suitability of data Kaise-Meyer-Olkin (KMO), Measure of Sampling Adequacy and Bartlett's Test of Simplicity are conducted on the data. The KMO index ranges from 0 to 1 . The Bartlett's Test of Sphericity should be significant $(\mathrm{p}<.05)$ for factor analysis to be suitable.

Kaiser Meyer Olkin measure of sampling adequacy $\quad 0.789$

Bartlett's Test of Sphericity

2343.023

DF

775

$P$ value

0.005

The KMO test coefficient is .789 and the coefficient value is more than 0.5 signifies that the factors are appropriate and adequate. The approximate Chi-Square value is 2343.023 with 775 degree of freedom. These tests show that the data is appropriate.

Table 13: Total Variance Explained

\begin{tabular}{|c|c|c|c|c|c|c|c|c|c|}
\hline \multirow{2}{*}{$\begin{array}{c}\text { Compon } \\
\text { ent }\end{array}$} & \multicolumn{3}{|c|}{ Initial Eigen Values } & \multicolumn{3}{|c|}{$\begin{array}{l}\text { Extraction Sums of } \\
\text { Squared Rotations }\end{array}$} & \multicolumn{3}{|c|}{$\begin{array}{l}\text { Rotation Sums of } \\
\text { Squared Loadings }\end{array}$} \\
\hline & $\begin{array}{l}\text { Tot } \\
\text { al }\end{array}$ & $\begin{array}{l}\% \text { of } \\
\text { Variance }\end{array}$ & $\begin{array}{l}\text { Cumulati } \\
\text { ve }\end{array}$ & $\begin{array}{l}\text { Tot } \\
\text { al }\end{array}$ & $\begin{array}{l}\% \text { of } \\
\text { Varian } \\
\text { ce }\end{array}$ & $\begin{array}{l}\text { Cumulati } \\
\text { ve }\end{array}$ & $\begin{array}{l}\text { Tot } \\
\text { al }\end{array}$ & $\begin{array}{l}\% \text { of } \\
\text { Varian } \\
\text { ce }\end{array}$ & $\begin{array}{l}\text { Cumulati } \\
\text { ve }\end{array}$ \\
\hline 1 & $\begin{array}{l}11.5 \\
0\end{array}$ & 57.51 & 57.51 & $\begin{array}{l}11.5 \\
0\end{array}$ & 57.51 & 57.51 & $\begin{array}{l}5.4 \\
2\end{array}$ & 27.11 & 27.11 \\
\hline 2 & 2.21 & 11.08 & 68.59 & 2.21 & 11.08 & 68.59 & $\begin{array}{l}4.5 \\
4\end{array}$ & 22.69 & 49.80 \\
\hline 3 & 1.70 & 8.53 & 77.13 & 1.70 & 8.53 & 77.13 & $\begin{array}{l}4.2 \\
2\end{array}$ & 21.12 & 70.92 \\
\hline 4 & 1.02 & 5.10 & 82.23 & 1.02 & 5.10 & 82.23 & $\begin{array}{l}2.1 \\
4\end{array}$ & 10.70 & 81.62 \\
\hline 5 & 0.82 & 4.14 & 86.37 & 0.82 & 4.14 & 86.37 & $\begin{array}{l}0.9 \\
5\end{array}$ & 4.75 & 86.37 \\
\hline 6 & 0.55 & 2.78 & 89.15 & & & & & & \\
\hline 7 & 0.49 & 2.46 & 91.62 & & & & & & \\
\hline 8 & 0.43 & 2.15 & 93.78 & & & & & & \\
\hline 9 & 0.30 & 1.54 & 95.32 & & & & & & \\
\hline 10 & 0.28 & 1.43 & 96.76 & & & & & & \\
\hline
\end{tabular}




\begin{tabular}{|l|l|l|l|l|l|l|l|l|l|}
\hline 11 & 0.20 & 1.00 & 97.76 & & & & & & \\
\hline 12 & 0.14 & 0.70 & 98.47 & & & & & & \\
\hline 13 & 0.09 & 0.48 & 98.95 & & & & & & \\
\hline 14 & 0.08 & 0.41 & 99.37 & & & & & & \\
\hline 15 & 0.05 & 0.25 & 99.62 & & & & & & \\
\hline 16 & 0.04 & 0.20 & 99.82 & & & & & & \\
\hline 17 & 0.02 & 0.10 & 99.92 & & & & & & \\
\hline 18 & 0.00 & 0.04 & 99.97 & & & & & & \\
\hline 19 & 0.00 & 0.02 & 99.99 & & & & & & \\
\hline 20 & 0.00 & 0.01 & 100.00 & & & & & & \\
\hline
\end{tabular}

Table 14: Rotated Component Matrix

\begin{tabular}{|c|c|c|c|c|c|}
\hline & F1 & F2 & F3 & F4 & F5 \\
\hline PMJDY is helpful for the people & $\begin{array}{l}0.75 \\
8\end{array}$ & $\begin{array}{l}- \\
0.05 \\
8\end{array}$ & $\begin{array}{l}- \\
0.23 \\
7\end{array}$ & $\begin{array}{l}- \\
0.07 \\
8\end{array}$ & $\begin{array}{l}- \\
0.09 \\
0\end{array}$ \\
\hline $\begin{array}{l}\text { PMJDY helps in reducing the dependence on informal } \\
\text { sources }\end{array}$ & $\begin{array}{l}0.84 \\
3\end{array}$ & $\begin{array}{l}0.16 \\
5\end{array}$ & $\begin{array}{l}0.02 \\
4\end{array}$ & $\begin{array}{l}0.01 \\
6\end{array}$ & $\begin{array}{l}0.15 \\
6\end{array}$ \\
\hline PMJDY is useful in improving the standard of living & $\begin{array}{l}0.79 \\
2\end{array}$ & $\begin{array}{l}- \\
0.05 \\
1 \\
\end{array}$ & $\begin{array}{l}0.15 \\
0\end{array}$ & $\begin{array}{l}- \\
0.22 \\
1 \\
\end{array}$ & $\begin{array}{l}0.06 \\
7\end{array}$ \\
\hline PMJDY is useful in linking the savings to the banks & $\begin{array}{l}0.82 \\
6\end{array}$ & $\begin{array}{l}- \\
0.23 \\
3 \\
\end{array}$ & $\begin{array}{l}- \\
0.19 \\
1 \\
\end{array}$ & $\begin{array}{l}0.12 \\
4\end{array}$ & $\begin{array}{l}- \\
0.13 \\
4 \\
\end{array}$ \\
\hline PMJDY helps in solving the financial needs of the people & $\begin{array}{l}0.85 \\
4\end{array}$ & $\begin{array}{l}0.07 \\
6\end{array}$ & $\begin{array}{l}0.13 \\
5\end{array}$ & $\begin{array}{l}0.24 \\
9\end{array}$ & $\begin{array}{l}0.07 \\
2\end{array}$ \\
\hline $\begin{array}{l}\text { PMJDY is useful in improving the economic \& Social } \\
\text { development of the country }\end{array}$ & $\begin{array}{l}0.82 \\
5\end{array}$ & $\begin{array}{l}- \\
0.30 \\
8 \\
\end{array}$ & $\begin{array}{l}0.03 \\
8\end{array}$ & $\begin{array}{l}0.12 \\
0\end{array}$ & $\begin{array}{l}- \\
0.06 \\
2\end{array}$ \\
\hline $\begin{array}{l}\text { PMJDY is helpful in providing awareness about financial } \\
\text { services \& products }\end{array}$ & $\begin{array}{l}0.80 \\
1\end{array}$ & $\begin{array}{l}- \\
0.25 \\
8\end{array}$ & $\begin{array}{l}0.02 \\
3\end{array}$ & $\begin{array}{l}- \\
0.21 \\
2\end{array}$ & $\begin{array}{l}- \\
0.05 \\
5\end{array}$ \\
\hline $\begin{array}{l}\text { PMJDY is an effective policy measure to solve the problem } \\
\text { of financial exclusion }\end{array}$ & $\begin{array}{l}0.90 \\
4\end{array}$ & $\begin{array}{l}0.01 \\
0\end{array}$ & $\begin{array}{l}0.02 \\
2\end{array}$ & $\begin{array}{l}0.05 \\
7 \\
\end{array}$ & $\begin{array}{l}0.03 \\
0\end{array}$ \\
\hline $\begin{array}{l}\text { Banking staff are helpful in providing information about the } \\
\text { scheme }\end{array}$ & $\begin{array}{l}0.77 \\
9\end{array}$ & $\begin{array}{l}- \\
0.31 \\
5\end{array}$ & $\begin{array}{l}- \\
0.07 \\
0\end{array}$ & $\begin{array}{l}0.07 \\
8\end{array}$ & $\begin{array}{l}0.15 \\
0\end{array}$ \\
\hline
\end{tabular}




\begin{tabular}{|c|c|c|c|c|c|}
\hline $\begin{array}{l}\text { Banking officials are not inclined to prejudice in opening the } \\
\text { accounts }\end{array}$ & $\begin{array}{l}0.60 \\
0\end{array}$ & $\begin{array}{l}- \\
0.66 \\
7\end{array}$ & $\begin{array}{l}- \\
0.12 \\
0\end{array}$ & $\begin{array}{l}- \\
0.16 \\
2 \\
\end{array}$ & $\begin{array}{l}0.03 \\
2\end{array}$ \\
\hline Banking infrastructure is adequate to reach out the people & $\begin{array}{l}0.63 \\
8\end{array}$ & $\begin{array}{l}- \\
0.56 \\
8\end{array}$ & $\begin{array}{l}- \\
0.08 \\
3\end{array}$ & $\begin{array}{l}0.25 \\
7\end{array}$ & $\begin{array}{l}0.01 \\
0\end{array}$ \\
\hline People are aware of the issue of Rupay cards & $\begin{array}{l}0.83 \\
3\end{array}$ & $\begin{array}{l}0.01 \\
6\end{array}$ & $\begin{array}{l}0.41 \\
2\end{array}$ & $\begin{array}{l}0.04 \\
4\end{array}$ & $\begin{array}{l}0.05 \\
2\end{array}$ \\
\hline $\begin{array}{l}\text { People are aware of Rs One Lakh Accidental insurance } \\
\text { provided under the scheme }\end{array}$ & $\begin{array}{l}0.76 \\
4\end{array}$ & $\begin{array}{l}0.03 \\
5\end{array}$ & $\begin{array}{l}0.39 \\
1\end{array}$ & $\begin{array}{l}0.27 \\
1\end{array}$ & $\begin{array}{l}0.11 \\
7\end{array}$ \\
\hline $\begin{array}{l}\text { People are aware of Rs } 30000 \text { /- Life insurance provided } \\
\text { under the scheme }\end{array}$ & $\begin{array}{l}0.73 \\
7\end{array}$ & $\begin{array}{l}0.15 \\
5\end{array}$ & $\begin{array}{l}0.44 \\
1\end{array}$ & $\begin{array}{l}- \\
0.06 \\
8 \\
\end{array}$ & $\begin{array}{l}- \\
0.02 \\
4\end{array}$ \\
\hline $\begin{array}{l}\text { People are aware of Rs } 5000 \text { /- Overdraft facility provided } \\
\text { under the scheme }\end{array}$ & $\begin{array}{l}0.57 \\
8\end{array}$ & $\begin{array}{l}0.55 \\
4\end{array}$ & $\begin{array}{l}0.47 \\
9\end{array}$ & $\begin{array}{l}0.03 \\
1\end{array}$ & $\begin{array}{l}- \\
0.07 \\
9\end{array}$ \\
\hline PMJDY is an eye wash & $\begin{array}{l}- \\
0.73 \\
2 \\
\end{array}$ & $\begin{array}{l}- \\
0.37 \\
5 \\
\end{array}$ & $\begin{array}{l}0.35 \\
9\end{array}$ & $\begin{array}{l}- \\
0.09 \\
0\end{array}$ & $\begin{array}{l}- \\
0.14 \\
0\end{array}$ \\
\hline In the real sense, PMJDY can't help in poverty reduction & $\begin{array}{l}- \\
0.78 \\
9 \\
\end{array}$ & $\begin{array}{l}- \\
0.32 \\
0 \\
\end{array}$ & $\begin{array}{l}0.30 \\
7\end{array}$ & $\begin{array}{l}0.04 \\
2\end{array}$ & $\begin{array}{l}- \\
0.17 \\
8 \\
\end{array}$ \\
\hline $\begin{array}{l}\text { Information regarding the scheme is not adequately available } \\
\text { at banks }\end{array}$ & $\begin{array}{l}- \\
0.78 \\
5 \\
\end{array}$ & $\begin{array}{l}- \\
0.35 \\
6 \\
\end{array}$ & $\begin{array}{l}0.30 \\
3\end{array}$ & $\begin{array}{l}0.12 \\
0\end{array}$ & $\begin{array}{l}- \\
0.03 \\
0 \\
\end{array}$ \\
\hline $\begin{array}{l}\text { Processing of accounts under PMJDY is cumbersome and } \\
\text { time consuming }\end{array}$ & $\begin{array}{l}- \\
0.75 \\
3 \\
\end{array}$ & $\begin{array}{l}- \\
0.48 \\
3 \\
\end{array}$ & $\begin{array}{l}0.36 \\
0\end{array}$ & $\begin{array}{l}- \\
0.06 \\
2 \\
\end{array}$ & $\begin{array}{l}0.05 \\
2\end{array}$ \\
\hline $\begin{array}{l}\text { There is need to improve the awareness of the scheme among } \\
\text { the people }\end{array}$ & $\begin{array}{l}0.19 \\
2\end{array}$ & $\begin{array}{l}0.08 \\
7\end{array}$ & $\begin{array}{l}- \\
0.18 \\
6 \\
\end{array}$ & $\begin{array}{l}0.13 \\
6\end{array}$ & $\begin{array}{l}- \\
0.27 \\
7\end{array}$ \\
\hline
\end{tabular}

Table 15: Summary of factors influencing respondents' perception towards PMJDY

\begin{tabular}{|l|l|l|l|}
\hline $\begin{array}{c}\text { Name of the } \\
\text { factor }\end{array}$ & $\begin{array}{c}\text { Item } \\
\text { No }\end{array}$ & \multicolumn{1}{|c|}{ Variables } & \multicolumn{1}{|c|}{$\begin{array}{c}\text { Factor } \\
\text { Loading }\end{array}$} \\
\hline Wholesomeness & 1 & PMJDY is helpful for the people. & 0.750 \\
\hline & 3 & $\begin{array}{l}\text { PMJDY is useful in improving the standard of } \\
\text { living }\end{array}$ & 0.537 \\
\hline & 4 & PMJDY is useful in linking the savings to the banks & 0.896 \\
\hline & 5 & $\begin{array}{l}\text { PMJDY helps in solving the financial needs of the } \\
\text { people }\end{array}$ & 0.910 \\
\hline & 6 & $\begin{array}{l}\text { PMJDY is useful in improving the economic \& } \\
\text { Social development of the country }\end{array}$ & 0.880 \\
\hline & 8 & PMJDY is an effective policy measure to solve the & 0.818 \\
\hline
\end{tabular}




\begin{tabular}{|c|c|c|c|}
\hline & & problem of financial exclusion & \\
\hline & 9 & $\begin{array}{l}\text { Banking staff are helpful in providing information } \\
\text { about the scheme }\end{array}$ & 0.526 \\
\hline & 10 & $\begin{array}{l}\text { Banking officials are not inclined to prejudice in } \\
\text { opening the accounts }\end{array}$ & 0.596 \\
\hline & 12 & People are aware of the issue of Rupay cards & 0.838 \\
\hline \multirow[t]{4}{*}{ Awareness } & 13 & $\begin{array}{l}\text { People are aware of Rs } 1 \text { Lakh Accidental insurance } \\
\text { provided under the scheme }\end{array}$ & 0.547 \\
\hline & 14 & $\begin{array}{l}\text { People are aware of Rs 30000/- Life insurance } \\
\text { provided under the scheme }\end{array}$ & 0.563 \\
\hline & 7 & $\begin{array}{l}\text { PMJDY is helpful in providing awareness about } \\
\text { financial services \& products }\end{array}$ & 0.909 \\
\hline & 20 & $\begin{array}{l}\text { There is need to improve the awareness of the } \\
\text { scheme among the people }\end{array}$ & 0.089 \\
\hline \multirow[t]{2}{*}{ Leverage } & 15 & $\begin{array}{l}\text { People are aware of Rs 5000/- Overdraft facility } \\
\text { provided under the scheme }\end{array}$ & 0.743 \\
\hline & 2 & $\begin{array}{l}\text { PMJDY helps in reducing the dependence on } \\
\text { informal sources }\end{array}$ & 0.840 \\
\hline \multirow[t]{3}{*}{ Eye wash } & 11 & $\begin{array}{l}\text { Banking infrastructure is adequate to reach out the } \\
\text { people }\end{array}$ & 0.477 \\
\hline & 16 & PMJDY is an eye wash & 0.507 \\
\hline & 17 & $\begin{array}{l}\text { In the real sense, PMJDY can't help in poverty } \\
\text { reduction }\end{array}$ & 0.886 \\
\hline \multirow[t]{2}{*}{ Complicated } & 18 & $\begin{array}{l}\text { Information regarding the scheme is not adequately } \\
\text { available at banks }\end{array}$ & 0.839 \\
\hline & 19 & $\begin{array}{l}\text { Processing of accounts under } \text { PMJDY is } \\
\text { cumbersome and time consuming }\end{array}$ & 0.528 \\
\hline
\end{tabular}

Table 15 shows the various factor and their associated factors.

Wholesomeness: This is the most significant factor with $27.11 \%$ of the total variance explained. This factor consists of 9 statements that are associated with the wholesomeness aspect of PMJDY. The statements that are associated with this factor are PMJDY is helpful for the people (.750), PMJDY is useful in improving the standard of living (0.537), PMJDY is useful in linking the savings to the banks (0.896), PMJDY helps in solving the financial needs of the people (0.910), PMJDY is useful in improving the economic \& Social development of the country (0.880), PMJDY is an effective policy measure to solve the problem of financial exclusion (0.818), Banking staff are helpful in providing information about the scheme (0.526), Banking officials are not inclined to prejudice in opening the accounts (0.596) and People are aware of the issue of Rupay cards (0.838).

Awareness: This is the second highest significant factor with $22.69 \%$ of the total variance explained. It has 4 statements associated with this factor. They are that the People are aware of Rs 1 Lakh Accidental insurance provided under the scheme (0.547), People are aware of Rs 30000/- Life insurance provided under the scheme (0.563), PMJDY is helpful in providing 
awareness about financial services \& products (0.909) and there is need to improve the awareness of the scheme among the people (0.089).

Leverage: This is the next highest significant factor with $21.12 \%$ of the total variance explained. It has 2 statements associated with this factor. The statements associated with this factor are People are aware of Rs 5000/- Overdraft facility provided under the scheme (0.743) and PMJDY helps in reducing the dependence on informal sources $(0.840)$

Eye wash: This is the factor which is associated with 3 statements and has a variance of $10.70 \%$. The statements associated with this factor are Banking infrastructure is adequate to reach out the people (0.477), in the real sense, PMJDY can't help in poverty reduction (0.886) and PMJDY is an eye wash (0.507)

Complicated: This is the factor which is associated with 2 statements and has a variance of $4.75 \%$. The statements associated with this factor are Information regarding the scheme is not adequately available at banks (0.839) and Processing of accounts under PMJDY is cumbersome and time consuming $(0.528)$

\section{Findings}

- PMJDY scheme is known to most of the people. $40 \%$ of the people knew it through Bank officials and is followed by Friends \& Relatives with $21 \%$.

- $66 \%$ of the people have opened the accounts under the scheme. While interacting with these people they were having savings account which were opened earlier. Most of the respondents have their accounts with State Bank of India.

- $58 \%$ of the respondents have opened the accounts under the scheme to avail savings facility.

- $55 \%$ of the respondents are related to the agriculture sector.

- $59 \%$ of the respondents have opened the accounts under this scheme by producing Aadhaar \& Ration card at the banks.

- $41 \%$ of the accountholders under this scheme feel that timely benefits are provided to them by the banks where the accounts are opened.

- Factor analysis is used to understand the perception of the people towards PMJDY. The variables are under consideration were divided into five factors. Out of the factors Wholesomeness has $27.11 \%$ of the total variance. 9 statements are associated with it.

- It is followed by Awareness factor with $22.69 \%$ of the total variance with 4 statements namely Rs 1 Lakh Accidental insurance, Rs 30000/- Life insurance, awareness about financial services $\&$ products.

- It is followed by Leverage with $21.12 \%$ of variance. It has 2 variables namely the awareness about Rs 5000/- overdraft facility and the reduction on dependence on informal sources of finance.

- Eyewash is the next factor with $10.70 \%$ of the total variance. The statements are Banking infrastructure is adequate to reach out the people, PMJDY can't help in poverty reduction and PMJDY is an eye wash.

- The last factor is Complicated which is associated with 2 statements and has a variance of $4.75 \%$. The statements associated with this factor are Information regarding the scheme is 
not adequately available at banks and Processing of accounts under PMJDY is cumbersome and time consuming.

\section{Suggestions}

- A good number of accounts are opened under the scheme but the usage is limited. There is need to improve the transactions in these accounts which will be helpful for the people as well as the banks.

- The financial literacy levels are very less. There is need to conduct financial literacy programs in these areas. The usage of ATMs needs to be educated among the people. The usage of technology needs to be improved which helps in effective utilization of the banking services.

- The procedure to open accounts, operating the accounts, disbursement of loans needs to be simplified. This simplification will help to remove the fear of the people with the complex documents of the banking procedures.

- Bank staff needs to be trained on a regular basis which will help them in assisting the people more effectively.

- Local people must be recruited as Business correspondents as they better understand the local people. Opening of accounts, disbursement of loans, transactions in the account and recovery of the loans will be easy for them.

- Customised products and services needs to be introduced. These people have irregular incomes and the savings, loan repayments will also be irregular.

\section{References}

[1] Kuldeep Singh and Anand Singh Koden, "Financial Inclusion, Development and Its Determinate: A Empirical Evidence of Indian States", Axen Economic Review, Vol.53, No.1, April 2011, 2327.

[2] Prabhu P V, "Financial Inclusion Structure and States of Co-operative Credit and Banking Sector in India", Vinmaya, Vol.XXXII, No. 2, 2011, 13-17.

[3] Barhate G \& V Jagtap (2014) Pradhan Mantri Jan Dhan Yojana: National Mission of Financial Inclusion. Indian Journal of Applied Research, 4(12).

[4] Bhuvaneshwari, P, \& Pushpalatha, V. (2013). Social banking as an instrument for financial inclusion. Business and Economic Facts for You, 33 (8), 30-34.

[5] Katia Vikas (2013) Financial Inclusion forDirect Benefit Transfer Growth and hurdles. International Journal of Economic Commerce and Research, 3(5), 13-20.

[6] Thapar (2013) A study on the effectiveness of the financial inclusion program in India. VSRD International Journal of Business and Management Research, 3(6), 211-216.

[7] www.pmjdy.gov.in

[8] Ministry of Information and Broadcasting (2014): "Pradhan Mantri Jan Dhan Yojana (PMJDY)Roadmap," Kurukshetra, MoRD, GOI, New Delhi, Vol. 63, November 2014.

*Corresponding author.

E-mail address: kietmohan@gmail.com 